Published in the Thomist: A Speculative Quarterly 79 (2015): 615-639.

\title{
THE PERSONAL SIGNIFICANCE OF SEXUAL REPRODUCTION
}

\author{
By Chad Engelland \\ University of Dallas
}

\begin{abstract}
This paper reconnects the personal and the biological by extending the reach of parental causality. First, it argues that the reproductive act is profitably understood in personal terms as an "invitation" to new life and that the egg and sperm are "ambassadors" or "delegates," because they represent the potential mother and father and are naturally endowed with causal powers to bring about motherhood and fatherhood, two of the most significant roles a person may have. Second, it argues that even though God alone can create a spiritual soul, the human parents are not just the causes of their child's body; they are the secondary causes of the whole child. In this way, God acts as a kind of "sponsor" who enables the acceptance of the invitation issued by the parents, and he accepts it on behalf of the new human person that comes to be thanks to their invitation.
\end{abstract}

"Now Adam knew Eve his wife, and she conceived and bore Cain, saying 'I have gotten a man with the help of the Lord."' (Genesis 4:1, RSV-CE)

In one of the more colorful matters of philosophical biography, we know that on October 15, 1634, Descartes fathered a child with a maid named Helena Jans. ${ }^{1}$ He made notations that day predicting the conception of a child as a result of the act, and nine months later his daughter Francine was born. His adventure in biological experimentation had a lasting personal significance, and the untimely death of Francine at the age of five proved to be a cause of great sorrow for her devoted father. ${ }^{2}$ In the Third Meditation, Descartes says that parental efficient causality is limited to the production of the body. He writes that "insofar as I am a thinking thing, [my parents] did not even make me; they merely placed certain dispositions in the matter which I have always regarded as containing me, or rather my mind, for that is all I now take

\footnotetext{
${ }^{1}$ A. C. Grayling, Descartes: The Life and Times of a Genius (New York: Walker Publishing Co., 2006), $149-150$.

${ }^{2}$ Grayling, Descartes, 153.
} 
myself to be."3 In this way, the personal significance of his fathering Francine lacks theoretical support in his writings. He remains merely one of two biological contributors to Francine's impersonal biology. In what follows, I wish to overcome this dualism of the personal and the biological and to spell out the personal and composite meaning of human sexual reproduction and, in doing so, explain why we are justified in speaking of human sexual reproduction in personal terms as procreation.

The two inter-related beliefs that denigrate the significance of human sexual reproduction are (1) thinking of human biology in impersonal terms and (2) thinking that parents are the cause of the body and not the soul. ${ }^{4}$ I argue that, rightly understood, human biology and divine creation in fact enrich the personal significance of parental causality. In making my case, I restrict my consideration to the meaning of sexual reproduction. I do not discuss the meaning of sexuality in its own right, nor do I discuss related topics such as love and marriage. Looking at reproduction, I cast a backward glance at the sexual act that led to it. While reproduction has ethical ramifications, I limit this paper to an investigation of its intrinsic meaning as an issue for philosophical anthropology: What is distinctive about human sexual reproduction that warrants us calling it "procreation"?

\footnotetext{
${ }^{3}$ Meditations on First Philosophy, in The Philosophical Writings of Descartes, vol. II, trans. John Cottingham, Robert Stoothoff, and Dugald Murdoch (Cambridge: Cambridge University Press, 1984), 35.

${ }^{4}$ In a footnote to a text originally published in 1927, Dietrich von Hildebrand links these two challenges to the personal meaning of human reproduction. He writes that the personal meaning of procreation "is not affected by the fact that only in his body is man the product of union between the semen and ovum; the soul, on the contrary, is always God's immediate creation. For it remains true that the parents procreate a human body destined for the most intimate union with an immortal soul, and from which it actually receives its 'form' (anima forma corporis; the soul is the form of the body." This paper aims to spell out a solution to the apparent draining of parental causality that comes from biology and immediate creation. See In Defence of Purity: An Analysis of the Catholic Ideals of Purity and Virginity (New York, Sheed and Ward, 1935), 26.

${ }^{5}$ Among contemporary authors, I have benefitted especially from reflections on the nature of the human person by Kenneth Schmitz, Leon Kass, and Robert Sokolowski: Schmitz, The Texture of Being: Essays in First Philosophy, ed. Paul O'Herron (Washington, DC: The Catholic University of America Press, 2007) and Person and Psyche (Washington, DC: The Institute for the Psychological Sciences Press, 2009); Kass, The Hungry Soul: Eating and the Perfecting of Our Nature (Chicago: University of Chicago Press, 1999); and Sokolowski, Christian Faith and Human Understanding: Studies on the Eucharist, Trinity, and the Human Person (Washington, DC: The
} 
St. Thomas Aquinas provides the backdrop to my project. He expresses the personal significance of the body in metaphysical terms: "Having more potentiality than other intellectual substances, the human soul is so close to matter that a material reality is induced to share its own being, so that from soul and body there results one being in the one composite, though this being, as belonging to the soul, does not depend on the body." ${ }^{6}$ Because the intellectual soul is the substantial form of the body, it virtually contains within it animal powers of perception and animate powers of metabolism and reproduction. By consequence, even metabolism and sexual reproduction are, in the case of human beings, expressions of the one intellective soul. In a word, they are personal. Aquinas has the right principles for this topic; it is just a matter of developing the concrete employment of them in a genuinely personalistic way. At the same time, I prescind from historical questions concerning the thought of Aquinas. ${ }^{7}$ Mine is a speculative rather than historical venture. In approaching the issue, I assume four theses:

(a) Anthropology: The human being is a composite of soul and body. ${ }^{8}$

(b) Hylomorphism: The spiritual soul is the form of the body. ${ }^{9}$

(c) Personalism: The person is an intelligent and free being with spiritual significance. ${ }^{10}$

(d) Immediate creation: The human soul, being immaterial and subsistent, must be created by God alone. ${ }^{11}$

In light of these principles, I pose two questions:

(1) Granting theses $a, b$, and $c$, what is the personal significance of the biology of human reproduction?

Catholic University of America Press, 2006), and Phenomenology of the Human Person (New York: Cambridge University Press, 2008). My own contribution to the conversation can be found in Engelland, "Unmasking the Person," International Philosophical Quarterly 50 (2010): 447-460, "Heidegger and the Human Difference," Journal of the American Philosophical Association 1 (2015): 175-193, and Ostension: Word Learning and the Embodied Mind (Cambridge, MA: MIT Press, 2014).

${ }^{6}$ On Being and Essence, 2nd ed., trans. Armand Maurer (Toronto: Pontifical Institute of Medieval Studies, 1968), c. 4, p. 59. Emphasis mine.

${ }^{7}$ He sensibly followed the best science of his day, although its limitations led him to misconstrue the division of labor in parental causality. Now that we have microscopes we have a more detailed understanding of what is involved in sexual reproduction.

${ }^{8}$ Aquinas, STh, I, q. 75, a. 4.

${ }^{9}$ Aquinas, STh, I, q. 76, a. 1 and 4.

${ }^{10}$ Aquinas, STh, I, q. 29, a. 3.

${ }^{11}$ Aquinas, STh, I, q. 118, a. 2. 
(2) Granting theses $a, b, c$, and $d$, what is the personal significance of parental efficient causality?

I argue in the first three sections of the paper that the sexual act is best construed along personal lines as an "invitation" to new life and that the sex cells from the respective mother and father are as it were "ambassadors" or "delegates" that naturally bear this meaning in virtue of their causal powers. In the second three sections, I will argue that even though God alone can create a spiritual soul, human parents do not just cause their offspring's body to be. Rather they are the cause of the whole person, because their reproductive causality naturally avails itself of God's creative completion of their act.

\section{The SEXUAL Act AS AN InVITATION to MotherhoOd AND FATHERHOOD}

The sexual act has a unique kind of causality, which distinguishes it from other modes of efficient causality, and this for two reasons. First, the sexual act and the coming-to-be of a child are in fact separate events. Authoring a book and a book's being authored, making a cake and a cake's being made are single events analyzable into a causing and a being caused, but having sex and a child's coming-to-be are temporally distinct events. David Hume's analysis of efficient causality in terms of two events customarily conjoined has limited applicability here, for we do genuinely have two temporally distinct events. But of course even here Hume is wrong, for the two events are in fact causally linked. In the sexual act, the parents afford the occasion for a child to come to be. They are consequently responsible for the coming-to-be of the child. A second difference emerges here. What the would-be parents directly cause is a possibility; had they not had sex it would have been impossible for a child to come to be, impossible for them to become mother and father to the same child. In having sex, they make possible this entwined reality: the advent of a child and the assignment of the personal roles, mother and father. But 
this possibility in no way entails actuality. The coming-to-be of the child rests on factors

extrinsic to their decision to engage in the sexual act and is therefore not, strictly speaking, within their determining power. The woman's cycle and the man's sperm count are just two such factors. In having sex, the would-be parents dispose themselves to the possibility of a new life coming to be, a new life that would make them mother and father to the same child. They perform an action that makes possible the coming-to-be of a child.

I propose calling this making possible an "invitation," to make manifest the latent personal meaning of the act whereby the would-be-parents dispose themselves to the possibility of their child's coming-to-be. ${ }^{12}$ We speak in personal terms of inviting people to a wedding party, a birthday party, or a dinner party. In issuing the invitation, the hosts ask someone to be their guest at some celebratory event, which typically celebrates the communion of persons in one way or another. Issuing the invitation makes it possible for those invited to become guests, but this making-possible does not make-actual; it does not lie within the power of the host to decide who will attend, only to decide who may attend. Analogously, would-be parents become would-be hosts by engaging in the sexual act which in effect issues an invitation to a would-be child, whether or not it should be accepted. Of course, unlike an ordinary invitation, what is proposed is not an issue of place alone: please come to our home from yours. What is proposed is rather the coming-to-be of a person, substance and all: please come to be in our home. The

\footnotetext{
12 The application of the personal term "invitation" in this sphere is suggested by two related observations by Karol Wojtyla. First, he thinks people should be mindful that the sexual act involves "potential parenthood." Second, he says that the child, coming to be, is admitted by the parents into the family: "In any event, the parents, who are deeply aware that the child belongs to them, also from the first moment accept the child into their personal community as a new subject of this relationship and this comunio that allows people to mutually give themselves, give their humanity, to one another in a most intimate way." The concept of invitation allows us to connect these two points: engaging in sex issues an invitation to a child to come to be as a member of one's own family. See "Parenthood as a Community of Persons," in Person and Community: Selected Essays, trans. Theresa Sandok, OSM (New York: Peter Lang, 2008), 331 and 333, respectively.
} 
invitation is extended simultaneously to (a) the child that may come to be and (b) the mother and the father of the child that may come to be. Let me discuss each in turn.

(a) The act itself, regardless of one's intentions in engaging it, invites new life to come to be as its natural result. Just as it is in a host's power to invite someone to a party but not in their power to determine whether the person will in fact come, so it is not in the power of the wouldbe parents to determine whether a new person will in fact come to be as the result of the sexual act. Nevertheless, an invitation is an invitation in virtue of its being extended, not in virtue of its being accepted. Nor does issuing an invitation necessarily mean that we want it accepted. Consider the sorts of invitations we might feel socially obliged to make, for example to an obnoxious boss or boorish relatives. Though we issue such invitations we might hope they are not accepted. At the same time, in those cases that they are accepted we have to acknowledge that the recipients were invited, however insincerely. Invitations exercise a causality in virtue of being offered, not in virtue of the intentions behind the offering. ${ }^{13}$ The seventeen-year-old St. Augustine and his unnamed lover found themselves parents to Adeodatus "contrary to their intention." 14 They invited new life by freely engaging in the act, not by means of the intention that led them to engage in the act.

(b) The couple issues the invitation to a potential offspring and simultaneously they issue an invitation to each other: the man invites the woman to be the mother of the invited child and

\footnotetext{
${ }^{13}$ On the difference between the intrinsic meaning of an act and the motive for performing it, see G.E.M. Anscombe, who writes, "We always need to distinguish the intention embodied in an action from the further intention with which the action is done; I am here concerned only with the former. Whatever ulterior intentions you may or may not have, the question first arises: what intention is inherent in the action you are actually performing?" "You Can Have Sex without Children: Christianity and the New Offer," in Ethics, Religion and Politics: Collected Philosophical Papers, vol. 3 (Oxford: Blackwell, 1991), 86. Anscombe's distinction is a restatement of the Platonic rejoinder to Thrasymachus in the Republic: whatever the motive of the ruler, the intrinsic meaning of ruling is the good of the ruled.

${ }^{14}$ Confessions, trans. Henry Chadwick (Oxford: Oxford University Press, 1991), 4.2.2: "With her I learnt by direct experience how wide a difference there is between the partnership of marriage entered into for the sake of having a family and the mutual consent of those whose love is a matter of physical sex, and for whom the birth of a child is contrary to their intention [contra uotum] — even though, if offspring arrive, they compel their parents to love them."
} 
reciprocally the woman invites the man to be the father of the invited child. ${ }^{15}$ The roles "father" and "mother" are relative terms. No one is a father in general but always a father to someone in particular. Thus, each time another child comes to be, one becomes a father or a mother afresh. Each child gives us our fatherhood or motherhood again. Consequently, the advent of each child further entwines the personal identities of the father and mother, and familial roles are irrevocable. One can always end a friendship; neighbors can move away; and co-workers can retire or find employment elsewhere. But familial roles are enduring: once one is a mother one cannot cease to be one, even if one's child should die. ${ }^{16}$ Thus the invitation offers to the man and the woman something personal and lasting. Aristotle notes that the child is a good common to each, but this is not specific enough. ${ }^{17}$ The child is not just a common good; he or she is a personal good that establishes lasting reciprocal roles between the mother and the father.

To invite another to participate in human life and to invite another to participate with you in rearing that life constitutes a radical celebration of and affirmation of the goodness of life. It is, in this respect, very much like inviting someone to a party. Human life, as Aristotle observed, is different from mere animal association, because it is constituted by shared beliefs about the world rooted in the power of speech to represent. ${ }^{18}$ To bring a child up is not simply a matter of helping the child successfully navigate his or her biological environment; to bring up a child entails immersing the child in a personal world with a given language, a given culture, and

\footnotetext{
${ }^{15}$ Wojtyla regards the reciprocity as central: "The very essence of this social and communal system (this communio personarum) lies in the fact that the man's fatherhood always occurs through he woman's motherhood and, vice versa, the woman's motherhood through the man's fatherhood." See "Parenthood as a Community of Persons," 330.

${ }^{16}$ Wojtyla thinks that with the advent of a child, the parents "acquire a new property and a new state," and he describes this as "a new dimension, a new qualification, in their personal and social life." See "Parenthood as a Community of Persons," 329-330.

${ }^{17}$ Nicomachean Ethics, trans. W. D. Ross, rev. J. O. Urmson, in The Complete Works of Aristotle, ed. Jonathan Barnes (Princeton, NJ: Princeton University Press, 1984), 8.12, 1162a27-29: “And children seem to be a bond of union (which is the reason why childless people part more easily); for children are a good common to both and what is common holds them together."

${ }^{18}$ Politics, 1.2, 1253a9-18.
} 
beliefs about what is right, holy, and good. To invite a child to come to be is to affirm human life but also the particularity of the human life one enjoys and can share, jubilantly, with one's offspring. Naturally, there is much about any given person's situation that is not cause for celebration; still, to reproduce is to affirm the essential goodness of one's way of life, despite or even in the face of, one's undesirable but accidental conditions. The man and woman, by issuing an invitation to new life and thereby to each other as father and mother, at the same time affirm not only the physical desirability of each other but also the goodness of each other's way of life and the principles that guide it. The would-be father says in effect: I affirm not only the maternal capacities of your body but the essentials of your human way of life; the would-be mother says in effect: I affirm not only the paternal capacities of your body but the essentials of your human way of life. I want to share that way of life with you and whatever children may come to be.

When someone sends out an invitation to a party, the would-be host means that the recipient is welcome to attend; the arrival of the guest, of course, calls for the host to marshal his or her resources to make the guest feel at home: mi casa es su casa. ${ }^{19}$ It is possible, then, to distinguish the act of issuing an invitation from the act of welcoming the one invited. Hans Jonas approaches the relation between the issuance of the invitation and the reception of the child with considerable sobriety: "The radical insufficiency of the begotten as such carries with it the mandate to the begetters to avert its sinking back into nothing and to tend its further becoming. The pledge thereto was implicit in the act of generation." ${ }^{20}$ Issuing an invitation promises that the invitee will be welcomed.

\footnotetext{
${ }^{19}$ On the activity of reception, see Gabriel Marcel, The Mystery of Being, Vol. 1: Reflection and Mystery, trans. G. S. Fraser (South Bend, IN: St. Augustine's Press, 2001), 118.

${ }^{20}$ The Imperative of Responsibility: In Search of an Ethics for the Technological Age (Chicago: Chicago University Press, 1984), 134. Emphasis added.
} 
What about the uninvited guest? An authentic reception implies that although the guest was not invited he or she is welcome; the factual lack of an invitation has the status of an accident or oversight. For example, Agathon tells Socrates' uninvited companion in the Symposium, 'Welcome, Aristodemus! What perfect timing! You're just in time for dinner! I hope you're not here for any other reason-if you are, forget it. I looked all over for you yesterday, so I could invite you, but I couldn’t find you anywhere." ${ }^{21}$ The welcomed guest is implicitly invited whether or not an invitation was issued or received. One in fact only insists on having received an invitation when one is made to feel unwelcome by the gatekeepers to the affair. In the case of adoption, the adoptive parents invite a child to come and live with them and accept responsibility for that child's well-being. The child already came to be thanks to the invitation of the natural parents; here the adoptive parents fulfill the natural meaning of the act whereby the child came to be by affirming that the child is welcome to be. Their welcome, like Agathon's welcome of Aristodemus, ratifies the invitation issued by someone else: We would have invited you to be had we been able to, and we are terribly glad you have been invited to be by someone else.

Why regard only the human sexual act as an invitation and not all animal sexual acts in general? After all, I have emphasized that the act solicits new life quite independently of the intentions of the participants. Why not acknowledge that kangaroos and chimpanzees equally "invite" new life? The reason is twofold. First, only in the case of a human reproduction is the invitation addressed to another person; invitations to parties are addressed to people. An invitation offers itself to a free being who is subsequently free to accept or decline. Now, in this peculiar case, the invitee does not decide for himself or herself whether to accept, but in the

${ }^{21}$ Plato, "Symposium," trans. Alexander Nehamas and Paul Woodruff, in Plato: Complete Works, ed. John M. Cooper (Indianapolis, IN: Hackett Publishing Company, 1997), 174e. 
course of his or her life, the child can after the fact second the acceptance of the invitation and thank his or her parents for welcoming him or her into the world. Second, only in the case of human reproduction is the invitation issued by a human person, who, knowing the basics of the birds and the bees, can accept the natural meaning of the act as constituting a kind of invitation. ${ }^{22}$ Only the human person has an intellect and will, so only the human person can know the meaning of an act and will it accordingly.

\section{THE SPERM AND THE EgG AS AMBASSADORS WITH DELEGATED AUTHORITY}

Even on the biological level, there is a reciprocal causality between the man and woman at work. The sperm at ejaculation are not yet capable of fertilizing an egg; they have to spend time within the female's reproductive tract in order for capacitation to occur. The sperm need the female environment in order for their biological potentiality to be activated. Similarly, the egg of the female is in an arrested state of development, but, as soon as one sperm penetrates it, there is egg activation; among other things, a sudden release of free calcium brings about the completion of the second meiotic division in the egg, making half its genetic code ready to be united with the genetic code from the sperm; the extra other half will in time degenerate. ${ }^{23}$ On the biological level, then, there is a causal reciprocity between the man and woman: sperm need the woman's environment to be capacitated, and the egg needs the man's sperm to be activated. Together, the man's sperm and the woman's egg can and do bring about new human life, but the causal capacities they enjoy (and not just their exercise) are enabled by the presence of one to the

\footnotetext{
${ }^{22}$ Richard Dawkins accepts the same facts but draws a different conclusion. We humans are the only animals in a position to know what our selfish genes are up to, the only ones able to frustrate their designs by using contraception. Here, I work out a different way to highlight what is uniquely human: the ability to understand and freely deploy the process whereby the circle of human persons is widened. See The Selfish Gene: 30th Anniversary Edition (Oxford: Oxford University Press, 2006), 332.

${ }^{23}$ The biological details in this paragraph are taken from Richard E. Jones and Kristin H. Lopez, Human Reproductive Biology, 4th ed. (Amsterdam: Academic Press, 2014), 163-169.
} 
other. The reciprocity between man and woman that plays out on the biological level mirrors the reciprocity that plays out on the personal level in which each invites the other to be parent to the same child.

In view of the hylomorphic unity of the human person, I propose we regard human biology in personal terms, and to do so, I would like to take a page from Plato's playbook in the Republic, and propose the fittingness of political terms for shedding light on the personal. Now, in political terms, ambassadors are freely sent by proper authorities from one country to another where they are appropriately received as representatives of their native countries; they are not just from their native country; they are empowered to act in its name. Analogously, I think the sperm act as the representatives or ambassadors of the man on the biological level, and, in turn, the egg acts as the representative or ambassador of the woman on the biological level. Just as the ambassador of a nation acts with the authority of the nation as a whole, so the sperm and egg are authorized to act with the authority of the man and of the woman. The sperm and egg are naturally sent to meet one another, and if and when they do, their meeting bears with it the personal intention of each parent as embodied in the sexual act itself. The sperm and egg represent the personal act in the biological realm. Sperm capacitation would name the fact that an ambassador is only an ambassador when received into a foreign country in which it is empowered to act; ambassadors have no power to represent when they are in their home country or when they are somewhere other than where they have been empowered to act. Similarly, egg activation would name the fact that the presence of an ambassador instigates the authorization of someone to receive him. The reciprocity on the biological level reflects the reciprocity on the personal. The ability to become a father is itself a gift from a woman to a man and the ability to become a mother is itself a gift from a man to a woman. 
The sperm and the egg, as reciprocally enabled ambassadors, are authorized in virtue of being sent one to the other to bring about a new human person. They bear the invitation issued by the parents. Their meeting and fusion brings about a new human substance that exceeds the capacities of either the sperm or the egg on their own and that amounts to something more than the mere merging of their causal capacities; together they bring about a new human person that will, given the appropriate conditions, come to exercise all the capacities inherent in the human nature he or she enjoys. Neither the sperm nor the egg is a human person; they are ambassadors of human persons; but the being they are empowered to bring about is a human person. The result of their fusion is not just another organism but another person. As both Aristotle and Levinas point out, the child is "a second self" to the parents. ${ }^{24}$ Just as friendship widens one's own self by adopting the good of another as one's own, so parenting, brought about through the causality of the sperm and egg uniting, widens one's own selfhood by identifying another's own good as one's own by virtue of having caused him or her to be. This new self that comes to be comes to be thanks to the personal powers harbored by the sperm and the egg.

Let me spell out the analogy a little more. Consider the way the international space station came about. To simplify things, let's reduce the participating counties to two, the U.S. and Russia. Vice President Al Gore, representing the United States, and Prime Minister Viktor S. Chernomyrdin, representing Russia, together established something new, independent of either country: a joint international space station. ${ }^{25}$ They could do so because they had the power to act in the name of the whole. The biological ambassadors of the man and the woman similarly

\footnotetext{
${ }^{24}$ Aristotle writes, "Parents, then, love their children as themselves (for their issue are by virtue of their separate existence a sort of other selves)." Nicomachean Ethics 8.12,1161b27-29. Levinas writes, "Paternity is a relation with a stranger who while being Other ... is me, a relation of the I with a self which yet is not me. In this 'I am' being is no longer Eleatic unity. In existing itself there is a multiplicity and a transcendence." Totality and Infinity, trans. Alphonso Lingis (Pittsburgh: Duquesne University Press, 1969), 277.

${ }^{25}$ Richard Berke, "Gore Signs Pacts in Moscow on Joint Shuttle Crews and Oil and Gas," New York Times, Dec. $17,1993$.
} 
sent together bring about something new that is independent of either parent. The difference here is that this new life is more than a new joint operation; it is more like a new country, capable, in time, of dispatching its own representatives.

The personal causality enjoyed by the sex cell works quite independently of the purposes of the people involved. The cells are authorized in virtue of being sent, whatever the reason may have been that they were sent. Suppose a married couple celebrating a recent promotion unintentionally gets drunk. While sloshed, they have sex only later to discover that the act led to the conception of a child. Clearly, they did not intend to have a child, for they did not even set out to have sex. Whatever their intention might have been, however, they engaged in the kind of activity whose natural meaningfulness constitutes an invitation to new life. They still dispatched their biological ambassadors to form, if possible, a new human life. They are still assigned the personal roles of mother and father to a new child thanks, in part, to the causality operative on the biological level. Because the human being as a whole is personal, biological activity is personal even apart from an explicit purpose designed to make it so. No matter the specific purposes of the agents, the act they engage in issues an invitation that may or may not be accepted. The biological ambassadors are authorized to act simply in virtue of being sent.

\section{A NOTE ON ANTHROPOMORPHISM}

About terms such as "ambassador" and "delegate" we are tempted to say they are anthropomorphic and so out of place in the realm of biology, but it must be remembered that our subject is none other than the anthropos, the human person, on various levels, so there can be no such thing as a misplaced anthropomorphism. Of course, other perils remain for such a speculative endeavor. There can be a part-whole fallacy in which the properties of the whole are ascribed to a part; an Olympian can be a good runner but the fingernail of an Olympian cannot 
be. In this case, the sex cell has different powers than the whole which produced it; it cannot do addition or subtraction, for example. It can, however, uniquely accomplish a deeply personal deed: human generation. The power of the whole person to reproduce is instantiated in precisely this part. Therefore, to regard sex cells in personal terms is not to fall prey to the part-whole fallacy.

The sex cells represent each person to each other. Consider the difference between an American tourist in Italy and an American ambassador in Italy. The behavior of the former might reflect favorably or poorly on America, but the tourist is nonetheless not capable of acting in the name of America. The ambassador, however, is not just a citizen but a representative, who can exercise genuine causality and can be received as such. The sex cell, like the ambassador and unlike the tourist, can exercise causality in the name of the would-be parent. A piece of hair might be taken as a token of a person and treasured accordingly. A fingerprint or drop of blood might serve as a trace of someone. These are pieces of one that indicate someone but do not represent someone. But the sex cells are not only traces of someone. They are causally efficacious in a particular way insofar as they are geared in their natures to bringing about a new human person. They therefore differ from other cells dispatched into the world. They are ambassadors rather than tourists.

Why do we resist the application of personal terms to human biology? Why does it seem unscientific to do so? The answer, I submit, is that we are captivated by the Cartesian idea of nature as res extensa. According to Descartes, an animal works in virtue of the mechanical forces in play; there is no need to posit a soul as animating principle. In this vein, the neuroscientist Antonio Damasio bemoans the fact that Descartes "persuaded biologists to adopt, 
to this day, clockwork mechanics as a model for life processes."26 The geneticist Richard Lewontin says the Descartes' clock metaphor informs "the entire body of modern science."27 Under the spell of Descartes, we think we are being scientific when we regard human biology in impersonal, mechanical terms that are species-neutral. ${ }^{28}$ Granting that such an approach can uncover valuable information about how human biology works, it is nonetheless the case that such an approach leaves out what is most important. If we want to understand human biology as human biology we cannot bracket the specifically human; we cannot leave out the world of persons. Of course, we might not want to count the application of personal terms to human biology as a contribution to modern biology, which seems methodologically committed to Cartesian principles; instead we can count it as a contribution to the philosophical understanding of what it means to be human.

\section{ORIGINS OF THE WHOLE OFFSPRING}

Aristotle saw parents and the divine operate in an allied manner: "The friendship of children to parents, and of men to gods, is a relation to them as to something good and superior; for they have conferred the greatest benefits, since they are the causes of their being and of their nourishment, and of their education from their birth. ${ }^{, 29}$ When we move from a pagan to a specifically theistic conception of the divine, this joint responsibility remains. God the Creator does not dilute parental causality; he enhances it. The parents operate together with the creator to be responsible for the whole human child. In this section, I want to work out a way for us to

${ }^{26}$ Descartes' Error: Emotion, Reason, and the Human Brain (New York: A Grosset/Putnam Book, 1994), 248.

${ }^{27}$ The Triple Helix: Gene, Organism, and Environment (Cambridge, MA: Harvard University Press, 2000), 3.

${ }^{28}$ See Leon Kass, "The Permanent Limitations of Biology," in Life, Liberty and the Defense of Dignity: The Challenge for Bioethics (San Francisco: Encounter Books, 2002).

${ }^{29}$ Nicomachean Ethics 8.12, 1162a4-8. 
think about the contribution of the parents in personal terms; they do not just cause the body to be, for they are the cause of the whole human being. My task here is to propose a way of thinking about the interface of the human and divine contribution in the genesis of another human person. Naturally, the causality of any secondary cause is due to the primary cause; the causality I am assigning to human parents does not compete with divine causality. My question is not how a secondary cause and a primary cause can be the cause of the same effect. Rather, I want to know how something that can be accomplished on the level of secondary causality interfaces with something that can occur only on the primary level. How does something God can as it were delegate become one with an act that cannot be so delegated?

On this question, Karl Rahner and Norris Clarke each see part of the truth. Rahner, emphasizing God's transcendent causality as sustainer of existence, denies any difference between the process whereby a person comes to be and the process whereby any other animal comes to be. The difference, rather, lies in the term of the production. Robert North ably summarizes Rahner's views as follows:

The parents produce a human being. And God produces the human being. Each exerts the causality of its own order. ... God is truly and immediately the creator of the human "soul" or life-principle of the living being. Essentially his activity here is the same as in his production of new animal or inorganic being; but the special term "creation" is applied because of the dignity of its end product. ${ }^{30}$

The parents, on this view, are the secondary causes of the whole human being without remainder. Clarke recoils before Rahner's suggestion, because he thinks it undermines the spiritual character of the human person and because it suggests that human parents, hours or in fact days after having sex, are causing to be another human person even though they may be sleeping, golfing,

${ }^{30}$ Teilhard and the Creation of the Soul (Milwaukee: The Bruce Publishing Company, 1967), 239. Rahner wrote the forward to the book. 
or watching television, and he finds this unseemly. Instead, Clarke proposes that parents cause the body alone:

Now the production of a new human child, endowed with an immortal spiritual soul, is the direct collaboration of both earth and heaven: of earth through the body that the parents have prepared as the highest point of the evolutionary thrust of the material world coming up from below; of heaven by the direct, loving collaboration of the Creator himself, introducing the realm of spirit into matter in this most unique of all creatures, an embodied spirit. ${ }^{31}$

Clarke is right that Rahner compromises the specific character of the human person in assimilating its mode of production to any other event in creation. But Clarke is wrong on two counts. First, he neglects the specific character of human reproduction as an invitation. The personal intention of the invitation occurs when it is issued, not when it is accepted, so it is not at all unseemly that the parents should be oblivious to the precise moment of its acceptance.

Second, parental causality must somehow extend to the whole child, and this for several reasons. Let me spell out why I take this to be.

Aquinas sensibly maintains that divine causation does not compete with creaturely agency: "God works in things in such a manner that things have their proper operation." the proper operation of all living beings includes the ability to reproduce their own kind. If people cannot reproduce people, they lack an operation proper to living beings. ${ }^{33}$ On Clarke's

31 "The Immediate Creation of the Human Soul by God: Some Contemporary Challenges," in The Creative Retrieval of Saint Thomas Aquinas: Essays in Thomistic Philosophy, Old and New (New York: Fordham University Press, 2009), 180.

${ }^{32}$ STh, trans. English Dominicans (New York: Benzinger Brothers, 1947), I, q. 105, a. 5.

${ }^{33}$ Aquinas calls the parental contribution the dispositive cause, which is completed by God as the perfective cause, who alone can generate the immaterial human intellect. Parents not only dispose matter to receive the rational soul but in doing so they transmit human nature to their offspring: "the semen by its own power transmits the human nature from parent to child." See STh I, q. 118, a. 2, ad 4, and STh I-II, q. 81, a. 1, ad 1 (trans. English Dominican Fathers [New York: Benzinger Brothers, 1947]), respectively. For the distinction between dispositive and perfective efficient causality, see Phys. II, lect. 5 (Commentary on the Physics of Aristotle, trans Richard J. Blackwell, Richard J. Spath, and W. Edmund Thirlkel [New Haven: Yale University Press, 1963], §180). In what follows, I underscore the invitational character of dispositive causality, the ordinariness of God's creative completion of it, and the unity of the 
view, human parents would exercise less causality for their offspring than would pigs for their piglets, because the boar and sow are not just the cause of the piglet's body but of the animating principle of the body as well. Second, a living body does not exist independently of its living form or soul. Therefore, parents can only cause the flesh on the condition that God simultaneously creates a human spirit to animate it, and, ordinarily God creates a human spirit to animate a body only on the condition that human parents are making their contribution. ${ }^{34}$ Since God and the parents both provide necessary conditions for human generation, the child that comes to be owes its undivided existence both to God and to his or her parents. Third, the responsibility and authority to educate offspring is a direct consequence of the causality of the parents in the act of procreation. The responsibility and authority to educate extends to spiritual matters (parents do not just feed and potty train; they should introduce the true, the good, and the beautiful). Therefore, their causality must extend to the whole human person. Fourth, with the advent of the child, the issuers of the invitation become a father and a mother, two of the most significant personal roles one can enjoy; these roles, as we have seen, are relative, insofar as one is mother to a particular child, but this relativity must be grounded in the personhood of the offspring. Parents are not, as it were, foster parents of the human persons that are their children; they enjoy the personal roles of father and mother because they are the father and mother of the whole human person that comes to be. For all these reasons, parental causality in reproduction must somehow extend to the whole person, spirit included.

\section{The Ordinary Primary Completion of a SECONDARy ACT}

dispositive and perfective causes in the effect produced. It is in this way that parents, as dispositive causes, are responsible for the coming to be of the whole child.

${ }^{34}$ I do not wish to suggest that God could not create a human being independent of other human beings only that he ordinarily does not do so. 
Let's say two brothers, Noah and Isaac, are in the woods and a bear begins to attack Isaac. Noah swings his gun around, aims, and shoots the bear dead. Isaac thanks him for killing the bear and saving his life. Noah replies, "I did not kill the bear, for that was beyond my power. Rather, the gun killed the bear." Isaac would think he was not taking the credit that was due him, for he is the one who wielded the gun, aimed, and fired; without him, the bear would not have died. Analogously, we can say that the human parents are causes of the whole human being even though God alone creates the immaterial human spirit, for the parents avail themselves of God's creative completion of the invitation they issue. The parents are able to make use of a power greater than their natural power in such a way that they are still the agents of the act, just as the hunter is still the agent when he fires a gun. God takes up and completes the contributions of the human parents. He enables them to exercise their parental causality.

I do not wish to suggest, of course, that God is as it were an instrument of parental causality. In this respect, the analogy with the gun fails. Rather, God as creator is the primary agent and in the exercise of his causality he enables other agents to be and to exercise their proper agency. Paradoxically, human parents naturally reproduce by virtue of a personal agency that exceeds the capacities of their own natures. Aquinas confronts a similar paradox in the case of human happiness. By nature we are capable of achieving happiness even though this lies beyond our power, because we are endowed with the freedom with which we might turn to God and be made happy. He writes:

Just as nature does not fail man in necessaries, although it has not provided him with weapons and clothing, as it provided other animals, because it gave him reason and hands, with which he is able to get these things for himself; so neither did it fail man in things necessary, although it gave him not the wherewithal to attain Happiness: since this it could not do. But it did give him free-will, with which he can turn to God, that He may make him happy. As Aristotle writes, "For what we do by means of our friends, is done, in a sense, by ourselves." 35

${ }^{35}$ STh, I-II, q. 5, a. 5, ad 1. 
God the Creator is not an impersonal instrument for parental causality; he is the ever faithful friend whose agency naturally completes the agency of human nature. Humans freely invite a new life by virtue of engaging in the act that dispatches their representatives, and God can and does complete their action by bringing about a new human being, which includes something they naturally could not cause, an immortal soul. Just as happiness is our natural end even though it can be accomplished only through divine agency, so parental efficient causality of the whole human being is natural to human sexual reproduction. Divine friendship brings human parental causality to its natural completion.

The invocation of friendship here might appear foreign to the sobriety of metaphysical considerations, but the God which functions in the question of this section is the God of theism. Aristotle's deistic divinity impossible to befriend or the pagan understanding of whimsical divinities manipulated through sacrifices do not function in this conception at all. God is the creator, who is eternal, wise, and loving. Friendship designates the fact that the creator wills the good of the human person. In creating a creature, he wills the good of that creature. For humans, the good includes that each should enjoy existence thanks to human parents and that some might be able to enjoy the personal roles of mothers and fathers.

We may be tempted to think of God's creation of the human soul as a miracle. Indeed, if one defines "miracle" as any effect that cannot be accomplished save by God alone, then creation itself and the creation of the human soul in particular is a miracle. Ordinarily, however, we think of a miracle as something that happens occasionally outside the ordinary course of nature. And in this case, God's creation of the human soul is not a miracle. Rather it belongs to the ordinary course of nature. Every time a sperm and egg successfully fuse, every time a human being comes to be, God creates its human soul. The God of theism does not hesitate as it were at the 
moment of fertilization: shall this a human being I make? His sovereignty over human generation comes through providence over the factors of fertilization (including the meeting of the two parents) not over whether or not fertilization will involve the infusion of a rational soul. That happens as a matter of course. Rahner objects that "however much the normality of this is stressed, it assumes a miraculous appearance. ${ }^{36}$ Rahner's worry can be addressed by noting that the appearance in this case is deceptive, and it does not warrant denying the specificity of the human mode of production. The naturalness of God's creative causality concerning the advent of a new human person is akin to the naturalness of divine illumination (independent of course as to whether or not this account of necessary truths is true). It is natural or part of the regular workings of things without being able to be accounted for fully in terms of secondary causality.

I can formulate this view in the following theses:

(a) God is the sole cause of the human spirit.

(b) Humans are secondary causes for the whole human being.

(c) To reconcile $a$ and $b$, we can say: human efficient causality naturally (and necessarily) is completed by divine causation, so to issue the invitation for a new life to come to be constitutes being the secondary efficient cause for the whole human being that may come to be through God's primary causality.

\section{GOD AS SPONSOR FOR THE INVITATION AND SURROGATE FOR ITS ACCEPTANCE}

Human parents are the human cause of the whole being of their offspring, even though the creation of the human spirit (itself the soul of the body) exceeds their natural causality. God regularly takes up and completes their causality, such that to be a human parent means to participate in a power that is more than human, but to so participate in something more than human is a natural ability characteristic of being human. In this way, the invitation accomplished in the sexual union is not only addressed to a potential child; it is simultaneously

${ }^{36}$ Hominisation: The Evolutionary Origin of Man as a Theological Problem, trans. W. T. O'Hara (Freiburg: Herder and Herder, 1968), 96. 
issued to the creator who would cooperate in bringing that child into existence. The creator here would be a kind of sponsor of the child, enabling the child to accept the invitation. God as sponsor enables the parental invitation to be fulfilled and what the parents invite by their act is not just a body but a human being, a body-soul composite. Parents do not create the spiritual soul of their offspring, but their invitation does cause to be the whole human child, including his or her spiritual soul, thanks to the sponsorship of the creator.

Let me draw out the meaning of sponsorship. A corporate sponsor, for example, might bring about an exhibition at the local natural history museum. But this sponsorship makes possible the causality of the exhibit designers, who are the ones who choose the topic and develop the displays. The sponsor provides only the necessary means for their specific causality to be realized. The sponsor does not compromise but enables their responsibility for the exhibit. Again, consider the role of sponsors for Olympic teams and other sporting events. We do not say that the sponsor wins the gold or that the medalist did not act on his or her own power because of the sponsorship. Instead, while acknowledging the genuine and non-negligible sponsorship, we nonetheless celebrate the genuine and non-negligible achievement of the Olympian. Similarly, God's sponsorship of the parental invitation has to do with affording them the resources to fulfill the invitation issued by their agency.

In the order of nature, fertilization is a chance event requiring the delivery of a capable delegation from the father and the availability of an ambassador from the mother. But God, outside the order of nature, is in a position to orchestrate chance events without compromising their contingency. ${ }^{37}$ In this way, we can say that God accepts the invitation on behalf of the child

${ }^{37}$ On the compatibility of chance and providence, see Thomas Aquinas, Commentary on the Metaphysics of Aristotle, trans. John P. Rowan (Chicago: Henry Regnery Company, 1961), §§1202-1222, and Robert Sokolowski, Eucharistic Presence: A Study in the Theology of Disclosure (Washington, DC: The Catholic University of America Press, 1993), 42-51. 
that comes to be. Due to the character of the invitation which proposes the very genesis of a being, the being in question cannot willingly accept the invitation except after the fact. ${ }^{38}$ God, providentially orchestrating chance causes, is the only agent positioned to accept the invitation before the fact, and he does so on behalf of the child that comes to be. Parents invite $a$ child to come to be; God can do something they cannot: he can choose that the invitation be accepted by willing this child to be. He creates each human person and creates each in its radical individuality as a person. Later, this child can will that it is good for him or her to be and in doing so he or she appropriates the original divine acceptance. She can thank her parents for their invitation and either implicitly or explicitly God for its possibility and acceptance. God the creator acts as a sponsor for the parents' invitation and a surrogate for the child's acceptance. His is a causality that enables people to be and to exercise genuine personal causality.

Several descriptions from the Confessions shed light on my claim. Augustine points out that neither his mother nor his wet nurses filled their own breasts. God, author of nature and human nature, sustainer of these women's existences, is the one ultimately responsible for the fact that the infant Augustine was welcomed and nurtured: "For the good which came to me from them was a good for them; yet it was not from them but through them."39 The activity of any secondary cause can be attributed primarily to the creator. However, when it comes to generation, Augustine calls Patricius and Monica "the parents of my flesh, him from whom and her in whom you formed me in time. ${ }^{, 40}$ Augustine is right to see generation as a special case, for no secondary cause can create a human person. However, as I have argued, Augustine here

${ }^{38}$ See Schmitz, The Gift: Creation (Milwaukee: Marquette University Press, 1982), 32-34, 80-81, and 128130.

${ }^{39}$ Confessions, 1.6.7.

${ }^{40}$ Confessions, 1.6.7. My emphasis. 
unnecessarily restricts parental causality. ${ }^{41}$ Monica and Patricius issued an invitation that a child may come to be, and God the providential creator made it possible for the invitation to be accepted. Indeed, at the close of Book IX, Augustine asks the reader to pray for his parents, "through whose flesh [per quorum carnem] you brought me into this life." ${ }^{42}$ Insofar as the advent of the child comes as the fulfillment of an invitation freely issued by freely engaging in the sexual act, the child owes its whole existence to its parents, for they were the ones that asked God to create and provided the opportunity for that to occur. Now, this parental act of invitation is something that, occurring on the secondary level, can be attributed primarily to the creator as well, but just as his nurses really did provide milk for the infant Augustine, so Monica and Patricius really did issue the invitation. God accepted the invitation and used it as an occasion to create Augustine in particular.

In making us human persons (and not angels), God at the same time gives us a genealogy, rich with personal and indeed spiritual significance for parent and child alike. Consider the anguish of Monica over Augustine's fall and the reassurance given her by a bishop: "Go away from me: as you live, it cannot be that the son of these tears should perish."43 To be is to owe thanks both to the God who chooses for each of us to be and to our parents who issue the occasion for that choice to be exercised.

\section{CONCLUSION}

Human sexual reproduction is personally significant biologically and metaphysically. Biologically, insofar as the marital act itself, irrespective of the intentions to engage in the act,

\footnotetext{
${ }^{41}$ This restriction may be due to an uncertainty on his part concerning whether or not the soul pre-exists conception. See Gerard O'Daly, Augustine's Philosophy of Mind (Berkeley, CA: University of California Press, 1987), 15-20 and 199-203. If the soul did pre-exist, then the act of creation and the act of reproduction would be separate and unrelated events and the parents would be causes of the body alone.

${ }^{42}$ Confessions, 9.13.37. Translation modified.

${ }^{43}$ Confessions, 3.12.21.
} 
constitutes an invitation to potential new life. In the act, the spouses simultaneously invite each other to be mother or father to the invited child. In this way, the gametes of the man and the woman are agents of the invitation; they are ambassadors with the delegated authority to bring about the acceptance of the invitation. Metaphysically, insofar as God serves as the sponsor to bring about the completion of the issued invitation by creating and infusing a rational soul each time fertilization occurs, and insofar as God alone is in a position to accept the invitation on behalf of the child. In this way, the parents are responsible for the advent of the whole child as a body-soul composite even though the being of the child exceeds their own natural causality. When they welcome a child into their midst they ratify the original invitation whereby the child came to be thanks to divine sponsorship. The child, in turn, can arrive at that point in which he or she can affirm the goodness of the invitation's acceptance. In doing so, I suggest, the believer in providence can see a ratification of a decision made on behalf of the child by the creator in providentially orchestrating fertilization. Human reproduction is not just a biological act nor is it a biological act together with a theological act. Rather, it is a human act that deploys personal biological agents and avails itself of the personal theological power. The term procreation expresses the fact that human sexual reproduction is charged with such personal significance. ${ }^{44}$

\footnotetext{
${ }^{44}$ I am thankful to Gerard Wegemer, John Crosby, Kerri Lenartowick, David C. Schindler, and Martin Dober for their critical remarks on earlier versions of this article.
} 


\section{Works Cited}

Anscombe, G.E.M. "You Can Have Sex without Children: Christianity and the New Offer." In Ethics, Religion and Politics: Collected Philosophical Papers, vol. 3, 82-96. Oxford: Blackwell, 1991.

Aquinas, Thomas. On Being and Essence. 2nd ed. Translated by Armand Maurer. Toronto: Pontifical Institute of Medieval Studies, 1968. . Commentary on the Metaphysics of Aristotle. Translated by John P. Rowan.

Chicago: Henry Regnery Company, 1961. . Summa Theologiae. Translated by English Dominicans. New York: Benzinger Brothers, 1947.

Aristotle. Nicomachean Ethics. Translated by W. D. Ross. Revised by J. O. Urmson. In The Complete Works of Aristotle. Edited by Jonathan Barnes. Princeton, NJ: Princeton University Press, 1984.

Augustine. Confessions. Translated by Henry Chadwick. Oxford: Oxford University Press, 1991.

Clarke, W. Norris. "The Immediate Creation of the Human Soul by God: Some Contemporary Challenges." In The Creative Retrieval of Saint Thomas Aquinas: Essays in Thomistic Philosophy, Old and New. New York: Fordham University Press, 2009.

Damasio, Antonio. Descartes' Error: Emotion, Reason, and the Human Brain. New York: A Grosset/Putnam Book, 1994.

Descartes, René. Meditations on First Philosophy. In The Philosophical Writings of Descartes, vol. II. Translated by John Cottingham, Robert Stoothoff, and Dugald Murdoch. Cambridge: Cambridge University Press, 1984. 
Engelland, Chad. "Heidegger and the Human Difference." Journal of the American Philosophical Association 1 (2015): 175-193. Ostension: Word Learning and the Embodied Mind. Cambridge, MA: MIT Press, 2014. . “Unmasking the Person.” International Philosophical Quarterly 50 (2010): 447-460.

Grayling, A. C. Descartes: The Life and Times of a Genius. New York: Walker Publishing Co., 2006.

Jonas, Hans. The Imperative of Responsibility: In Search of an Ethics for the Technological Age. Chicago: Chicago University Press, 1984.

Jones, Richard E. and Kristin H. Lopez. Human Reproductive Biology, 4th ed. Amsterdam: Academic Press, 2014.

Hildebrand, Dietrich von. In Defence of Purity: An Analysis of the Catholic Ideals of Purity and Virginity. New York, Sheed and Ward, 1935.

Kass, Leon. The Hungry Soul: Eating and the Perfecting of Our Nature. Chicago: University of Chicago Press, 1999. . "The Permanent Limitations of Biology." In Life, Liberty and the Defense of Dignity: The Challenge for Bioethics. San Francisco: Encounter Books, 2002.

Levinas, Emmanuel. Totality and Infinity. Translated by Alphonso Lingis. Pittsburgh: Duquesne University Press, 1969.

Lewontin, Richard. The Triple Helix: Gene, Organism, and Environment. Cambridge, MA: Harvard University Press, 2000.

Marcel, Gabriel. The Mystery of Being, Vol. 1: Reflection and Mystery. Translated by G. S. Fraser. South Bend, IN: St. Augustine's Press, 2001. 
North, Robert. Teilhard and the Creation of the Soul. Milwaukee: The Bruce Publishing Company, 1967.

O’Daly, Gerard. Augustine's Philosophy of Mind. Berkeley, CA: University of California Press, 1987.

Plato. Symposium. Translated by Alexander Nehamas and Paul Woodruff. In Plato: Complete Works. Edited by John M. Cooper. Indianapolis, IN: Hackett Publishing Company, 1997.

Rahner, Karl. Hominisation: The Evolutionary Origin of Man as a Theological Problem. Translated by W. T. O’Hara. Freiburg: Herder and Herder, 1968.

Schmitz, Kenneth. Person and Psyche. Washington, DC: The Institute for the Psychological Sciences Press, 2009. . The Texture of Being: Essays in First Philosophy, ed. Paul O'Herron. Washington, DC: The Catholic University of America Press, 2007.

Sokolowski, Robert. Christian Faith and Human Understanding: Studies on the Eucharist, Trinity, and the Human Person. Washington, DC: The Catholic University of America Press, 2006.

. Eucharistic Presence: A Study in the Theology of Disclosure. Washington, DC: The Catholic University of America Press, 1993.

. Phenomenology of the Human Person. New York: Cambridge University Press, 2008.

Wojtyla, Karol. "Parenthood as a Community of Persons." In Person and Community: Selected Essays. Translated by Theresa Sandok, OSM. New York: Peter Lang, 2008. 